\title{
Whether to wear a pollution filter
}

\section{Y. S. Chung ${ }^{1} \cdot$ C. $^{\text {Alves }^{2}}$ - B. Rappenglück ${ }^{3}$}

Published online: 17 June 2019

(C) Springer Nature B.V. 2019

When dust and air pollution concentrations are high, many people wear a "dust mask." In general, a "mask" covers the entire face. However, to protect oneself from breathing pollutants, one needs to cover only the nose and mouth. Thus, the term "half mask" is sometimes used. Since the function of the type of mask being discussed is to reduce dust particles and some gaseous pollutants, it could be more precisely called a "pollution filter," or dust filter.

The average adult breathes 12 to 25 times per minute (Flenady et al. 2017; Wikipedia, 2019). Each breath draws in $0.5 \sim 3.51$ of air into our respiratory organs depending on physical activity. We consume the least amount of air, at 61 per minute $(1 / \mathrm{min}$, based on $0.51 \times 12$ breaths $/ \mathrm{min})$ during sleep; about $20 \mathrm{l} / \mathrm{min}$ while sitting at rest; and about $87 \mathrm{l} / \mathrm{min}$ in running exercise. When we wear a pollution filter, our breathing rate has to increase by about $10 \%$ during walking to draw in the same amount of air. Therefore, doctors do not necessarily recommend wearing a pollution filter for individuals in weak respiratory health.

\section{Y. S. Chung}

Chungys22@gmail.com

1 Korea Centre for Atmospheric Environment Research, Cheongju 28177, Republic of Korea

2 University of Aveiro, Aveiro, Portugal

3 University of Houston, Houston, USA
While a pollution filter can help remove pollutants from intake ambient air, it does not work so well for removing pollutants from exhaled air. Exhaled air contains $\mathrm{CO}_{2}$ and possibly bacteria and viruses that could be trapped partly by the filter. It can be unhealthy to keep breathing the residual air recycled within some poorly designed filters. For this reason, we do not recommend wearing pollution filters. However, doctors in Korea and government agencies of many Asian countries routinely recommend wearing pollution filters when air pollution levels are high (Fig. 1).

As air quality scientists, we believe that poor-quality filters that hinder the removal of exhaled air should not be used. Furthermore, we recommend to not wear a pollution filter unless the outdoor particulate matter (PM) loadings are higher than $70 \mu \mathrm{g} / \mathrm{m}^{3}$ in $\mathrm{PM}_{2.5}, 150 \mu \mathrm{g} / \mathrm{m}^{3}$ in $\mathrm{PM}_{10}$, and $200 \mu \mathrm{g} / \mathrm{m}^{3}$ in TSP. These values are the results of our dust monitoring over 25 years (Chung et al. 2003). During heavy pollution episodes, pollution filters should not be worn for longer than 20 min without renewing. 


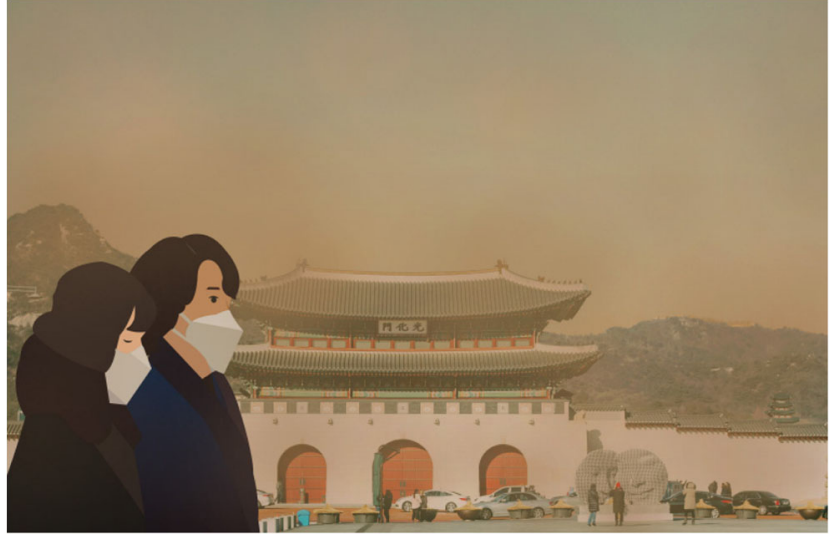

Fig. 1 Citizens wear a dust/pollution filter
Acknowledgments We thank J Chow, A Steinemann, W Lau, HS Kim, and $\mathrm{E}$ Chung for their valuable inputs suggested.

\section{References}

Chung YS, Kim HS, Han KY, Jugder D (2003) On east Asian sand and duststorms and associated significant dustfall observation from January to May 2001. Water, Air, and Soil Pollution: Focus 3 (2): 259-277

Flenady T, Dwyer T, Applegarth J (2017) Accurate respiratory rates count: so should you! Aust Emerg Nurs J 20:45-47

Wikipedia, online encyclopedia (2019) Respiratory rate

Publisher's note Springer Nature remains neutral with regard to jurisdictional claims in published maps and institutional affiliations. 